\title{
EFFECTS OF PLANT AGE, TOPOGRAPHY AND PROCESSING SYSTEM ON THE BIOCHEMICAL TRAITS AND QUALITY OF TEA
}

\author{
Md Sakib Hossain, Rayhan Uddin, Pranti Barua, Md Yasin, \\ Mohammad Shameem Al Mamun ${ }^{1}$ and Md Mozammel Hoque* \\ Department of Food Engineering and Tea Technology, Shahjalal University of \\ Science and Technology, Sylhet, Bangladesh \\ Keywords: Tea, Biochemical traits, Quality, Plant age, Topography, Processing
}

\begin{abstract}
Laboratory experiment was conducted to study the biochemical and quality parameters of tea i.e. Polyphenol, Theaflavin (TF), Thearubigin (TR), Caffeine, Lipid, Total ash, Chlorophyll, Moisture content etc. under different variables designed for age, topography, and processing system imposed on an established tea orchard. Results revealed that plant age and topography do not have any significant effect on most of the studied parameters. In case of plant age, tannin is found to be significantly higher in mature tea plant (39.35 ppm) whereas young plant showed significantly lower total sugar content $(28.98 \mathrm{ppm})$. In case of land elevation, significantly higher tannin $(37.41 \mathrm{ppm})$ and lower carotenoid content $(0.74 \mathrm{mg} / \mathrm{g})$ were evident in plants from kunchi topography where flat topography showed significantly higher total sugar (26.62 ppm) in leaves. The handmade tea flavoured with significantly higher amount of polyphenol $(58.57 \mathrm{ppm})$ and caffein $(43.30 \mathrm{ppm})$ but industry made tea showed significantly higher amount of tannin $(37.65 \mathrm{ppm})$, total sugar (15.25 ppm) and TF:TR (1:10).
\end{abstract}

\section{Introduction}

Tea (Camellia sinensis (L.) O. Kuntze) is a popular health beverage in the world, produced from the leaves of evergreen shrub. Tea is the second most popularly consumed non-alcoholic beverage (Khizar et al. 2015) which is one of the important functional foods. It becomes a leading cash crop in modern world agriculture with boosting production and of cultivating area (Dutta et al. 2010). Being native to the humid tropics and subtropics, it can also be grown in a wide range of climatic conditions and soils. Geographical areas that receive an annual rainfall of at least 1200 $\mathrm{mm}$ per year and have a mean average temperature of $30^{\circ} \mathrm{C}$ along with soil $\mathrm{pH} 4.5-5.6$ are the most favorable for growth and cultivation of tea (Hajiboland 2017). The quality and quantity of tea depend on a variety of factors, including different cultural practices, climate, altitude, season, the type and age of the plant and process involved in preparing tea (Rahman et al. 2014, Khizar et al. 2015). Black teas from higher altitude resulted in higher levels of TFs and its fractions, aroma composition, and water extract while crude fiber remained unaffected (Muthumani et al. 2013). In most tea growing regions, younger tea plantations have been associated with higher productivity while declining or stagnant yields are observed in older plantations (Illukpitiya et al. 2004). Normally with aging roots become woodier, crowded and less effective for uptake and transport of water along with nutrients and result in variation/decrease in yield, quality, and chemical composition (Kibblewhite et al. 2014). As one of the pedogenic factors, topography can be an important and effective factor on yield and quality of crop performance through affecting water distribution and soil properties in different landscape positions (Yaghmaeian et al. 2020). Elevation has a major effect on the quality of tea. As elevation increases, the growth rate of the shoot decreases. Factors that contribute towards slower growth at high altitudes also lead to improved quality of tea (Owuor et al. 1990).

*Author for correspondence: <hoquemm@gmail.com>. ${ }^{1}$ Bangladesh Tea Research Institute, Srimangal, Moulvibazar, Bangladesh. 
Processing methods of tea resulted in variation in chemistry and quality parameters. Weathering, fermentation, drying, grading etc. are the different processes involved in tea manufacturing (Zhu et al. 2015). All the stages are associated with several chemical reactions which determine the quality of tea (Teshome 2019). Polyphenolic compounds are the quantitatively major component of tea leaves and are mainly responsible for the unique character of different processed teas according to its degree of fermentation (Khalesi et al. 2014). In North Bengal of Bangladesh, teas are largely cultivated in farmer level and due to lack of mechanization they use handmade tea to fulfill their thirst for divine drinks. Therefore, preparation of tea may be categorized as handmade tea, semi-manual tea, factory processed tea. Most of the processing is done by hand along with the help of natural sunlight. The tea processing strategies possesses significant effect on the taste and chemical composition of tea (De Mejia et al. 2009). Optimum fermentation conditions and duration are best for sensory quality and the highest content of TFs.

Very little information are available about how chemical constituents' profile and quality parameters change in relation to preparation procedure and plant age. Therefore, the aim was to study effects of land topography, age of tea bushes and tea preparation procedure on physical and biochemical parameters as well as the quality of made tea.

\section{Materials and Methods}

The quality determining experiment was carried out at the laboratory of Department of Food Engineering and Tea Technology (FET), Shahjalal University of Science and Technology (SUST), Sylhet. Tea shoots comprising apical bud and subtending two leaves were harvested from the main farm of BTRI (Bangladesh Tea Research Institute), Moulvibazar, Bangladesh. The experimental sections were categorized according to the bush ages as (i) Young ( 0 to 5 years), ii) Mature (5 to 40 years) and iii) Old (above 40 years) and topographic position of the plantation viz. (i) Flat (38m from MSL, Mean Sea Level), (ii) Tillah (70 m from MSL) and iii) Kunchi (92 m from MSL). Chlorophyll contents of tea shoots were measured using the method suggested by Wellburn (1994).Total polyphenols were estimated spectrophotometrically using method of Dev-Choudhury and Goswami (1983). Total theaflavins (TF) and thearubigins (TR) were estimated by method of Roberts and Smith (1963) and crude lipids were measured gravimetrically by the method of Ravichandran and Parthiban (2000). Tannin content and caffeine were determined using method of Amorim et al. (2008) and Maidon et al. (2012), respectively. Total ash was determined according to AACC (2000) method. Total sugar was estimated according to Hedge and Hofreiter (1962). The scavenging effect of tea extract on DPPH radical was estimated according to the method of Chan et al. (2007). Water extract was estimated by following the methods reported by the AOAC (2005). The whole experiment was carried out in the replication system. The experimental data were statistically analyzed by IBM SPSS Statistics version 20 statistical software and mean values are adjusted by Duncan's Multiple Range Test (DMRT) at 5\% level of significance.

\section{Results and Discussion}

The tests were triplicated for each sample and the contents of chemical constituents were calculated based on the dry weight. The Chlorophyll a, Chlorophyll $\mathrm{b}$ and Carotenoids were found to range from 3.94 to $9.72,3.03$ to 6.39 and 0.73 to $1.28 \mathrm{mg} / \mathrm{g}$, respectively. Similar types of values of photosynthetic pigments were observed by Mamun et al. (2016) in fresh leaves. The principal product of chlorophyll degradation are therefore pheophorbides and pheophytins, which lead to the dark color of black tea. Fig. 1 shows that there exists no significant variation of photosynthetic pigments due to age variation in standing crop. In case of topographic position, the 
kunchi and tillah plantation scored significantly higher amount of chlorophyll a and carotenoid than that of flat plantation. Table 1 shows that, there exists no significant variation in polyphenol and caffeine content among the plantation relating to age and topographic position separately. On the other hand, handmade tea possessed highest polyphenol content $(58.57 \mathrm{ppm})$ than semimanual $(42.19 \mathrm{ppm})$ and industry made tea $(36.18 \mathrm{ppm})$. The caffeine content of handmade and semi manual tea was also significantly higher than that of industry made tea. The reason might be that handmade tea did not go through with high temperature oriented mechanical process which could bring biochemical changes in leaves at withering period. As a result, polyphenols retained themselves from being converted to TF and TR (Owuor and Obanda 1996). The tannin content in matured, young and old plantation were $39.35,38.30$ and $33.43 \mathrm{ppm}$, respectively where in tillah, flat and kunchi were 34.04, 31.12 and $37.41 \mathrm{ppm}$, respectively. Similar types of scores of tannin content were also observed by Ahmad et al. (2016).
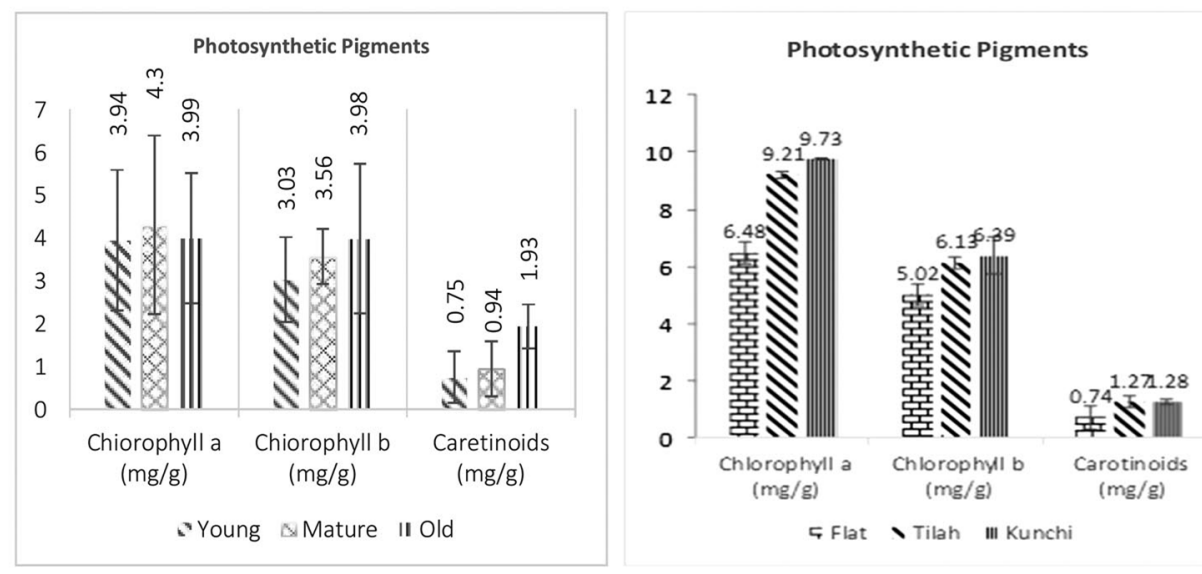

Fig. 1. Effect of age of plant (A) and land topography (B) on the photosynthetic pigments' contents of leaves.

In case of processing system, tannin content of semi-manual and industry made tea was significantly of higher amount than that of handmade tea. The sugar content of matured plantation was significantly higher than that of young plantation. Sugar content in flat plantations was significantly higher than that of rest two categories of elevation. It was also found that there exists no significant difference in TF, TR, TF : TR, HPS, TLC, CI level among the plantations considering age and topographic position. Total liquor color depends on the quantity of TF and TR content as they are responsible for briskness and brightness and color and strength, respectively (Owuor and Obanda 2001). The TF content in industry made tea scored significantly higher amount than that of handmade and semi manual tea. This might be due to the variation in conversion of polyphenol with different processing system. The TF: TR ratio of made tea was found optimum in processed tea whereas others merely fluctuated or deviated. Relating to TF and TR content the tea sample exhibit respective HPS, TLC and CI. From Table 2, it is apparent that there exists no significant variation in the scavenging effect at a concentration level of $0.2 \mathrm{mg} / \mathrm{ml}$. At 0.4 and $0.6 \mathrm{mg} / \mathrm{ml}$ concentration level, the scavenging effect of the matured plantation was significantly higher than that of the rest two plantations. The scavenging effect of the matured plantation was higher. This might be due to the higher tannin content which with protein and alkaloids together can scavenge. The scavenging effect tangentially related to the antioxidant content present in the sample. 
Table 1. Effect of plant age, topography and processing system on the biochemical traits and quality of tea samples.

\begin{tabular}{|c|c|c|c|c|c|}
\hline Parameter & Sample & $\begin{array}{l}\text { Polyphenol } \\
\text { (ppm) }\end{array}$ & $\begin{array}{l}\text { Caffeine } \\
(\mathrm{ppm})\end{array}$ & $\begin{array}{c}\text { Tannin } \\
(\mathrm{ppm})\end{array}$ & $\begin{array}{l}\text { Total sugar } \\
(\mathrm{ppm})\end{array}$ \\
\hline \multirow[t]{3}{*}{ Plant age } & Young & $42.39 \pm 3.97^{\mathrm{a}}$ & $44.65 \pm 1.82^{\mathrm{a}}$ & $38.30 \pm 4.45^{\mathrm{a}, \mathrm{b}}$ & $28.98 \pm 3.88^{b}$ \\
\hline & Matured & $48.95 \pm 8.29^{a}$ & $44.75 \pm 0.89^{a}$ & $39.35 \pm 0.61^{\mathrm{a}}$ & $40.07 \pm 3.16^{\mathrm{a}}$ \\
\hline & Old & $40.18 \pm 4.72^{\mathrm{a}}$ & $43.77 \pm 0.52^{\mathrm{a}}$ & $33.43 \pm 1.96^{\mathrm{b}}$ & $35.20 \pm 2.56^{\mathrm{a}, \mathrm{b}}$ \\
\hline \multirow{3}{*}{$\begin{array}{l}\text { Topographic } \\
\text { position }\end{array}$} & Flat & $38.98 \pm 12.92^{\mathrm{a}}$ & $50.74 \pm 4.61^{\mathrm{a}}$ & $34.04 \pm 2.75^{\mathrm{b}}$ & $26.62 \pm 6.37^{\mathrm{a}}$ \\
\hline & Tillah & $31.29 \pm 6.28^{\mathrm{a}}$ & $52.08 \pm 1.00^{\mathrm{a}}$ & $31.12 \pm 0.76^{\mathrm{b}}$ & $11.65 \pm 1.77^{\mathrm{b}}$ \\
\hline & Kunchi & $37.06 \pm 10.67^{\mathrm{a}}$ & $49.70 \pm 2.6^{\mathrm{a}}$ & $37.41 \pm 0.61^{\mathrm{a}}$ & $17.39 \pm 7.50^{\mathrm{b}}$ \\
\hline \multirow{3}{*}{$\begin{array}{l}\text { Processing } \\
\text { system }\end{array}$} & Handmade & $58.57 \pm 1.97^{\mathrm{a}}$ & $43.30 \pm 1.38^{\mathrm{a}}$ & $29.46 \pm 0.5^{\mathrm{b}}$ & $7.18 \pm 0.22^{\mathrm{c}}$ \\
\hline & Semi-manual & $42.19 \pm 0.75^{\mathrm{b}}$ & $42.00 \pm 1.14^{\mathrm{a}}$ & $38.84 \pm 1.54^{\mathrm{a}}$ & $19.58 \pm 1.08^{\mathrm{a}}$ \\
\hline & Industry made & $36.18 \pm 2.08^{c}$ & $31.02 \pm 1.28^{\mathrm{b}}$ & $37.65 \pm 1.57^{\mathrm{a}}$ & $15.25 \pm 1.01^{\mathrm{b}}$ \\
\hline \multicolumn{6}{|c|}{ Right side of Table 1.} \\
\hline $\mathrm{TF}(\%)$ & $\mathrm{TR}(\%)$ & TF:TR & HPS (\%) & $\operatorname{TLC}(\%)$ & Color Index \\
\hline $0.86 \pm 0.26^{\mathrm{a}}$ & $7.91 \pm 2.52^{\mathrm{a}}$ & $1: 9.24$ & $13.09 \pm 1.31^{\mathrm{a}}$ & $6.94 \pm 4.06^{\mathrm{a}}$ & $4.92 \pm 1.14^{\mathrm{a}}$ \\
\hline $0.87 \pm 0.46^{\mathrm{a}}$ & $8.75 \pm 4.33^{\mathrm{a}}$ & $1: 10.25$ & $11.11 \pm 0.74^{\mathrm{a}}$ & $7.99 \pm 4.73^{\mathrm{a}}$ & $4.23 \pm 1.55^{\mathrm{a}}$ \\
\hline $0.66 \pm 0.32^{\mathrm{a}}$ & $8.30 \pm 2.42^{\mathrm{a}}$ & 1:11.13 & $12.44 \pm 2.41^{\mathrm{a}}$ & $4.48 \pm 0.34^{\mathrm{a}}$ & $3.41 \pm 2.25^{\mathrm{a}}$ \\
\hline $1.03 \pm 0.42^{\mathrm{a}}$ & $11.40 \pm 2.05^{\mathrm{a}}$ & $1: 11.08$ & $13.93 \pm 3.10^{\mathrm{a}}$ & $4.91 \pm 1.34^{\mathrm{a}}$ & $5.5 \pm 1.67^{\mathrm{a}}$ \\
\hline $0.80 \pm 0.16^{\mathrm{a}}$ & $7.62 \pm 1.73^{\mathrm{a}}$ & $1: 9.29$ & $15.95 \pm 3.79^{\mathrm{a}}$ & $5.68 \pm 0.30^{\mathrm{a}}$ & $3.45 \pm 0.93^{\mathrm{a}}$ \\
\hline $0.78 \pm 0.04^{\mathrm{a}}$ & $7.95 \pm 1.45^{\mathrm{a}}$ & 1:10.13 & $18.21 \pm 4.11^{\mathrm{a}}$ & $5.04 \pm 0.94^{\mathrm{a}}$ & $3.26 \pm 0.23^{\mathrm{a}}$ \\
\hline $0.79 \pm 0.16^{\mathrm{c}}$ & $7.33 \pm 1.34^{\mathrm{a}}$ & $1: 9.21$ & $8.79 \pm 1.37^{\mathrm{a}}$ & $2.18 \pm 0.19^{b}$ & $5.92 \pm 0.45^{\mathrm{a}}$ \\
\hline $0.80 \pm 0.11^{\mathrm{b}}$ & $9.16 \pm 0.78^{\mathrm{a}}$ & $1: 11.38$ & $7.31 \pm 0.54^{\mathrm{a}, \mathrm{b}}$ & $2.69 \pm 0.39^{\mathrm{a}}$ & $2.83 \pm 0.23^{\mathrm{b}}$ \\
\hline $0.84 \pm 0.051^{\mathrm{a}}$ & $8.45 \pm 0.60^{\mathrm{a}}$ & $1: 10.00$ & $6.54 \pm 0.41^{\mathrm{b}}$ & $2.92 \pm 0.03^{\mathrm{a}}$ & $2.53 \pm 0.72^{b}$ \\
\hline
\end{tabular}

Values are expressed as Mean \pm SD, different letter(s) are significantly different by DMRT (p > 0.05).

Table 2. Scavenging effect of different aspects of tea samples.

\begin{tabular}{llccc}
\hline Parameter & Sample & \multicolumn{3}{c}{ Scavenging effect $(\%)$} \\
& & $\begin{array}{c}0.2 \\
(\mathrm{mg} / \mathrm{ml})\end{array}$ & $\begin{array}{c}0.4 \\
(\mathrm{mg} / \mathrm{ml})\end{array}$ & $\begin{array}{c}0.6 \\
(\mathrm{mg} / \mathrm{ml})\end{array}$ \\
\hline Plant age & Young & $94.94 \pm 1.65^{\mathrm{a}}$ & $97.07 \pm 0.06^{\mathrm{b}}$ & $98.06 \pm 0.07^{\mathrm{b}}$ \\
& Mature & $94.97 \pm 0.86^{\mathrm{a}}$ & $97.75 \pm 0.23^{\mathrm{a}}$ & $98.87 \pm 0.01^{\mathrm{a}}$ \\
& Old & $88.90 \pm 6.11^{\mathrm{a}}$ & $96.33 \pm 0.08^{\mathrm{c}}$ & $98.06 \pm 0.08^{\mathrm{b}}$ \\
\cline { 2 - 5 } Topographic & Flat & $92.89 \pm 0.73^{\mathrm{b}}$ & $97.9 \pm 1.02^{\mathrm{b}}$ & $97.9 \pm 1.20^{\mathrm{b}}$ \\
position & Tillah & $95.96 \pm 0.85^{\mathrm{a}}$ & $99 \pm 0.33^{\mathrm{a}}$ & $99 \pm 0.87^{\mathrm{a}}$ \\
& Kunchi & $80.96 \pm 1.03^{\mathrm{c}}$ & $97.26 \pm 1.52^{\mathrm{b}}$ & $95.65 \pm 2.03^{\mathrm{c}}$ \\
\cline { 2 - 5 } Processing & Hand made & $95.22 \pm 0.21^{\mathrm{a}}$ & $97.57 \pm 0.09^{\mathrm{a}}$ & $98.33 \pm 0.26^{\mathrm{a}}$ \\
system & Semi-manual & $94.27 \pm 0.70^{\mathrm{a}, \mathrm{b}}$ & $95.75 \pm 0.19^{\mathrm{b}}$ & $97.85 \pm 0.01^{\mathrm{a}}$ \\
& Industry made & $93.32 \pm 0.20^{\mathrm{b}}$ & $91.32 \pm 0.34^{\mathrm{c}}$ & $91.02 \pm 0.16^{\mathrm{b}}$ \\
\hline
\end{tabular}

Values are expressed as Mean $\pm \mathrm{SD}$, different letter(s) are significantly different by DMRT ( $\mathrm{p}>0.05)$. 
In every concentration level the scavenging effect significantly higher in tillah plantation. The reason might be as the volatile content tends to go upward which reduces attack of pest and insects. Similarly, the scavenging effect was much more prominent in hand made tea than rest two processing. The reason might be due to the contribution of polyphenol and tannin content. Similar types of score were observed by Chowdhury et al. (2016) in fresh tea leaves.

Samples show lipid content between 6.582 and $8.18 \%$. Ash levels range was 5.76 to $7.11 \%$ in the analyzed samples (Fig. 2). Rahman et al. (2014) found similar types of result in different green long tea samples. In analysis, no significant differences were observed in lipid and ash content among the samples of each category of plant age, topography and processing system separately. It is evident that for good quality tea the lipid contents and ash content should be lower in amount (Selvendran et al. 1978, Ahmed et al. 1989). The results of scores of moistures presented in Table 3 show that the range was 0.52 to $5.06 \%$, which is similar with the findings of Harler (1964). According to Kumar et al. (2005), the variation in the moisture may be attributed to the degree of drying type and nature of tea involved. The water extract was laid between 14.04 and $20.39 \%$. No significant variation was observed in moisture, dry matter and water extract among the samples of age and topographic categorization separately whereas in case of processing system semi manual tea scored significantly higher amount of water extract percentages and significantly lower amount of moisture and dry mater percentages.

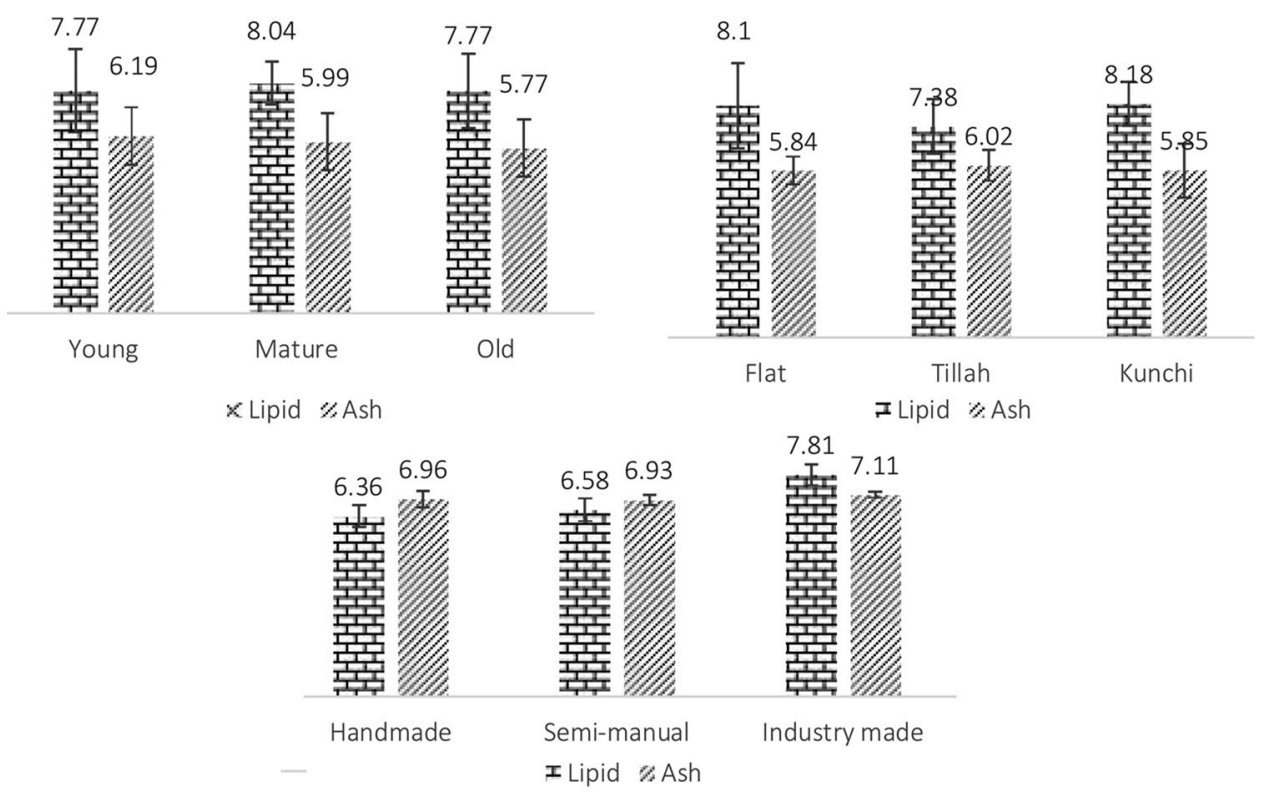

Fig. 2. Effect of age of plant (A), topography (B) and processing system (C) on lipid and ash content in tea samples.

There is a significant effect of plant age, topography and processing system on the biochemical traits and quality of tea. The plant age and topographic position influenced the parameters like tannin content, total sugar and scavenging effect where no significant variation was observed for rest of the parameters. It is evident that color, appearance, flavor and liquoring characteristics jointly constitute the tea quality. So, it can be concluded that considering useful constituents and quality tea leaves can be collected from any of the plantations and more 
specifically considering the scavenging effect leaves can be collected from the matured plantation. Among the topographical positions, Tillah contain the high amount of polyphenol, caffeine, antioxidant, ash content, chlorophyll $\mathrm{b}$ and low amount of reducing sugar, total lipid and tannin content. In processing system, the handmade tea possesses significantly higher amount of polyphenol, caffeine, and antioxidant capacity. But all other qualities were found to be better in industry made tea.

Table 3. Moisture, Dry matter and Water extract of different tea samples.

\begin{tabular}{llccc}
\hline Parameter & Sample & Moisture $(\%)$ & Dry matter $(\%)$ & Water extract $(\%)$ \\
\hline Plant age & Young & $3.88 \pm 0.46^{\mathrm{a}}$ & $96.12 \pm 0.46^{\mathrm{a}}$ & $20.39 \pm 2.55^{\mathrm{a}}$ \\
& Mature & $4.18 \pm 0.41^{\mathrm{a}}$ & $95.82 \pm 0.41^{\mathrm{a}}$ & $19.59 \pm 1.47^{\mathrm{a}}$ \\
& Old & $5.06 \pm 1.65^{\mathrm{a}}$ & $94.94 \pm 1.65^{\mathrm{a}}$ & $18.88 \pm 2.24^{\mathrm{a}}$ \\
\cline { 2 - 5 } Topographic & Flat & $0.82 \pm 0.45^{\mathrm{a}}$ & $99.18 \pm 0.45^{\mathrm{a}}$ & $20.38 \pm 2.08^{\mathrm{a}}$ \\
position & Tillah & $0.52 \pm 0.36^{\mathrm{a}}$ & $99.48 \pm 0.36^{\mathrm{a}}$ & $19.59 \pm 1.18^{\mathrm{a}}$ \\
& Kunchi & $0.94 \pm 0.28^{\mathrm{a}}$ & $99.06 \pm 0.28^{\mathrm{a}}$ & $18.88 \pm 1.83^{\mathrm{a}}$ \\
\cline { 2 - 5 } Processing & Handmade & $3.99 \pm 1.18^{\mathrm{a}}$ & $96.82 \pm 1.35^{\mathrm{a}}$ & $14.04 \pm 0.09^{\mathrm{c}}$ \\
system & Semi-manual & $1.51 \pm 0.34^{\mathrm{b}}$ & $98.82 \pm 0.34^{\mathrm{b}}$ & $20.28 \pm 1.18^{\mathrm{a}}$ \\
& Industry made & $3.71 \pm 1.13^{\mathrm{a}}$ & $96.42 \pm 1.26^{\mathrm{a}}$ & $18.42 \pm 0.91^{\mathrm{b}}$ \\
\hline
\end{tabular}

Values are expressed as Mean \pm SD, different letter(s) are significantly different by DMRT $(\mathrm{p}>0.05)$.

\section{References}

AACC 2000. Approved methods of the American Association of Cereal Chemists. 10th ed. The Association, St. Paul, MN, USA. 1200 pp.

Ahmad I, Das TT, Yasin M and Hossain MA 2016. Study on biochemical compounds, antioxidant activity and organoleptic taste of some spice tea. Agric. Food Sci. Res. 3(2): 53-58.

Ahmed I, Zaidi S and Khan Z 1989. Determination of major, minor and trace elements in tea, tea liquor, instant coffee and cocoa samples. Pak. J. Sci. Ind. Res. 32(8): 513-515.

Amorim EL, Nascimento JE, Monteiro JM, Peixoto ST, Araújo TA and Albuquerque UP 2008. A simple and accurate procedure for the determination of tannin and flavonoid levels and some applications in ethnobotany and ethnopharmacology. Fun. Eco. Com. 2: 88-94.

AOAC 2005. Official Methods of Analysis of the Association of Analytical Chemists. 17th edn. Washington DC, USA.

Chan EWC, Lim YY and Chew YL 2007. Antioxidant activity of Camellia sinensis leaves and tea from a lowland plantation in Malaysia. Food. Chem. 102: 1214-1222.

Chowdhury RS, Moly IS, Ahmed M, Mamun MSA, Hoque MM and Miah MF 2016. Impact of the mosquito bug (Helopeltis theivora) infestation on the quality of tea (Camellia sinensis).Bangladesh J. Zool. 44: 197-207.

De Mejia EG, Ramirez-Mares MV and Puangpraphant S 2009. Bioactive components of tea: cancer, inflammation and behavior. Brain Behav. Immun. 23(6): 721-731.

Dev-Choudhury M and Goswami M 1983. A Rapid Method for the Estimation of Total Polyphenolic Matters in Tea Camellia Sinensis L. Two \& A Bud 30: 59-61.

Dutta R, Stein A, Smaling E, Bhagat R and Hazarika M 2010. Effects of plant age and environmental and management factors on tea yield in Northeast India. Agron. J. 102(4): 1290-1301. 
Hajiboland R 2017. Environmental and nutritional requirements for tea cultivation. Folia Hortic. 29(2): 199-220.

Harler C 1964. The cultivation and marketing of tea. Oxford: Oxford University Press, London.

Hedge J and Hofreiter B 1962. Carbohydrate Chemistry, In: Whistler RL and Be Miller JN, pp. 17. Academic Press, New York.

Illukpitiya P, Shanmugaratnam N and Kjosavik DJ 2004. Tea Agroecosystems in the Uva Highlands of Sri Lanka. Mt. Res. Dev. 24(1): 52-60.

Khalesi S, Sun J, Buys N, Jamshidi A, Nikbakht-Nasrabadi E and Khosravi-Boroujeni H. 2014. Green tea catechins and blood pressure: a systematic review and meta-analysis of randomised controlled trials. Eur. J. Nutr. 53(6): 1299-1311.

Khizar Hayat, Hira Iqbal, Uzma Malik, Uzma Bilal and Sobia Mushtaq 2015. Tea and Its Consumption: Benefits and Risks. Crit. Rev. Food Sci. Nutr. 55(7): 939-954.

Kibblewhite MG, Prakash S, Hazarika M, Burgess PJ and Sakrabani R 2014. Managing declining yields from ageing tea plantations. J. Sci. Food Agri. 94: 1477-1481.

Kumar A, Nair A, Reddy A and Garg A 2005. Availability of essential elements in Indian and US tea brands. Food Chem. 89(3): 441-448.

Maidon AB, Mansoer AO and Sulistyarti H 2012. Study of various solvents for caffeine determination using UV spectrophotometric. J. Appl. Sci. Res. 8(5): 2439-2442.

Mamun MSA, Hoque MM, Ahmed M and Yasin M 2016. Physiological and biochemical changes in tea leaves and made tea due to red spider mite infestation. Asian J. Plant Sci. 15: 16-25.

Muthumani T, Verma D, Venkatesan S and Kumar R 2013. Influence of altitude of planting on quality of south Indian black teas. J. Nat. Prod. Plant Resour. 3:18-23.

Owuor PO and Obanda M 1996. The impact of withering temperature on black tea quality. J. Sci. Food Agric. 70(3): 288-292.

Owuor PO and Obanda M 2001. Comparative responses in plain black tea quality parameters of different tea clones to fermentation temperature and duration. Food Chem.72: 319-327.

Owuor PO, Obaga SO and Othieno CO 1990. The effects of altitude on the chemical composition of black tea. J. Sci. Food Agric. 50(1): 9-17.

Rahman M, Kalam M, Salam M and Rana M 2014. Aged leaves effect on essential components in green and oolong tea. Int. J. Agril. Res. Innov. Tech. 3(2): 54-58.

Ravichandran R and Parthiban R 2000. Lipid occurrence, distribution and degradation to flavour volatiles during tea processing. Food Chem. 68(1):7-13.

Roberts E and Smith R 1963. The phenolic substances of manufactured tea. IX.- the spectrophotometric evaluation of tea liquors. J. Sci. Food Agric. 14(10): 689-700.

Selvendran RR, Reynolds J and Galliard T 1978. Production of volatiles by degradation of lipids during manufacture of black tea. Phytochem. 17(2): 233-236.

Teshome K 2019. Effect of tea processing methods on biochemical composition and sensory quality of black tea (Camellia sinensis (L.) O. Kuntze): A review. J. Hortic. For. 11(6): 84-95.

Wellburn, Alan R 1994. The spectral determination of chlorophylls a and b, as well as total carotenoids, using various solvents with spectrophotometers of different resolution. J. Plant Physiol. 144(3): 307313.

Yaghmaeian MN, Nobahar DN, Rahimi MM and Fatemi CA 2020. Effect of topography on soil properties, yield and quality of tea in Lahijan region. Agril. Eng. Sci. J. Agric. 42(4): 55-74.

Zhu L, Li Y, Gai XY and Zhang LX 2015. Effect of different withering treatments on quality and chemical components of Shandong oolong tea. China Tea Pro. 2: 19-23.

(Manuscript received on 10 June, 2020; revised on 31 March, 2021) 